\title{
Analysis of the efficiency of national civil construction firms
}

\author{
Ari Francisco de Araújo Junior ${ }^{\dagger}$ \\ $I B M E C-M G$ \\ Daniela Guimarães Nogueira ${ }^{\Omega}$ \\ $I B M E C-M G$ \\ Cláudio D. Shikida ${ }^{¥}$ \\ IBMEC - MG
}

\begin{abstract}
The article analyzes the efficiency of national civil construction firms, through the application of Data Envelopment Analysis in multistage, for a pool of construction companies, between the years 2005 and 2008. The Malmquist index is used to calculate the variation in total factor productivity over the period, decomposing it into variations in technical and scale efficiency and technological progress. The results for our sample, point to significant differences in technical and scale efficiency according to the invoicing level and indicate that, on average, technical efficiency scores decreased between 2005 and 2008, as well as the variation in total productivity of factors. The average technical efficiency score for the period was 0.433 and showed a downward trend since 2006. The total factor productivity in the period from 2005 2008 , decreased by $7.2 \%$ due, mainly, to the negative variation in the technological progress.
\end{abstract}

Keywords: Efficiency; data envelopment analysis; civil construction.

* Corresponding authors:

${ }^{*}$ Master in Economics at UFMG Affiliation: Professor IBMEC - MG Address: Rua Rio Grande do Norte, No.300, Belo Horizonte - MG Brazil

E-mail: arifaj@ibmecmg.br Phone: (31) 3247-5757
Economist Ibmec Minas. Affiliation: IBMEC - MG Address: Rua Rio Grande do Norte, No.300, Belo Horizonte - MG - Brazil

E-mail: danguimar@gmail.com Phone: (31) 3247-5757
${ }^{¥}$ Ph.D. in Economics at UFRGS Affiliation: Professor IBMEC - MG Address: Rua Rio Grande do Norte, No.300, Belo Horizonte - MG - Brazil, 30130/130. E-mail: claudiods@ibmecmg.br Phone: (31) 3247-5757

Editor's note: This article has been accepted by Bruno Funchal 


\section{INTRODUCTION}

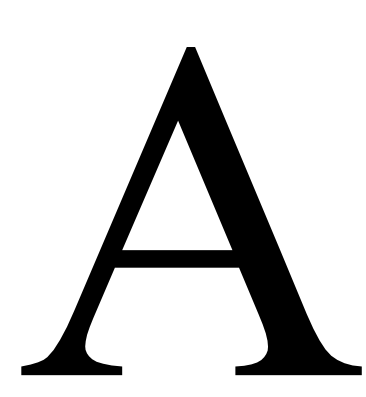

fter nearly two decades of stagnation, coupled with a deep crisis in 2004, the national construction industry seems, since then, to be recovering. Construction sites spread throughout the country, labor became scarce, wage levels have been redefined, land, inflated, and production inputs, particularly steel, have a strong and continuous increase in price levels.

Spurred by the boom in civil construction in Brazil, the main industry groups, especially those devoted to the activities of development, were launched in the capital market, by a process known as IPO - Initial Public Offer. Investors landed billions of dollars in shares of construction, emphasizing the need to supply the housing deficit and the various development programs launched by the Lula Government, in particular the Growth Acceleration Program $(P A C)^{\mathrm{ii}}$. Finally, the last year was also marked by the confirmation of Brazil as host country for the next FIFA World Cup, which should boost investment in infrastructure (renovation of stadiums, transportation networks, hospitals and airports, among others).

The rapid pace of construction was been interrupted in the last months of 2008, with the spread of American banking crisis for the global economy. Brazilian banks have adopted restrictive policies regarding the provision of new lines of credit, and interest, on a downward trend since 2002, resumed the other way round. Consumption contracted, the government suspended its development programs, and actions of the developers have lost value.

The surviving firms have adopted more conservative positions, including those related to fundraising and the use of productive inputs. Bank debts were renegotiated, the salaries and labor contingent, adjusted, clients at risk of default have been abandoned, many lands were returned, and their contracts canceled.

Faced with an industry still in rehabilitation, although supported by rather optimistic forecasts about future growth, ensuring the efficient construction firm becomes a task of paramount importance. The proper use of inputs has not only results in company profit, but also affects their competitiveness. Inefficient firms will hardly support themselves facing an increasingly fierce competition, thanks to the incentives and facilities provided by the current government.

This article seeks to measure the efficiency of Brazilian firms in the construction industry between 2005 and 2008, through data envelopment analysis. The goal is to measure 
the degree of efficiency of construction and point the dimension which each builder can work in to further improve its efficiency.

The article is divided into five other sections. The first comprises the literature review that highlights the evolution of concepts of efficiency, the main aspects related to its measurement techniques, and other articles that deal specifically with the efficiency of construction firms. The following section presents the methodology of DEA. Sections four and five present the database and model specification based on the chosen inputs and products, in addition to the main results. The last section concludes the argument.

\section{CONCEPTS OF EFFICIENCY, DATA ENVELOPMENT ANALYSIS (DEA) AND THE CASE OF CIVIL CONSTRUCTION}

Production is said to be technically efficient if there is no other way to produce more with the same number of factors or produce the same amount of product, using the least amount of inputs (Farrell, 1957).

Efficiency can be analyzed in its economic, technical and allocative aspects. While the former directs towards the monetary aspect of production, by evaluating the relationship between the value of products and value of inputs, the technique is concerned with its physical aspects, analyzing the firm's ability to produce as much product, given a particular quantity of inputs. Finally, allocative efficiency seeks to determine the optimal combination of inputs, given the price levels that maximize business results.

The theoretical literature on efficiency gained momentum with the work of Debreu (1951) and Shepard (1953), but it was Farrell (1957) who pioneered the empirical modeling of efficiency and frontiers, by developing the concept of structural efficiency of the industry, a dispersion indicator of global efficiency over the constituent firms in the industry. On the basis of a production frontier of a given firm, it was able to confront its relative effectiveness to the efficient frontier of the industry.

Farrell's works influenced Charnes, Cooper and Rhodes (1978) into developing the method of data envelopment analysis (DEA). The authors reformulated the linear programming model of Farrell, extending it to multiple outputs and inputs, and each firm started to be seen as a decision making productive unit (decision making unit - DMU). The DEA relies on Pareto-Koopmans's concept of efficiency, according to which "an organization is efficient if and only if it is not possible to increase the magnitude of any product or input without a reduction in other input or output" (Cooper, Sieford and Tone, 2000). 
For Delgado (2007), the non-parametric modeling of DEA has the advantage of being flexible, since it does not assume any functional form a priori to the frontier of production. Also, it may be applied to more than one product at the same time in an estimate. However, precisely because of its non-parametric format, convergence becomes slow, which may result in inconsistent estimators, especially when the sample is reduced.

Despite the several studies on the efficiency of firms from different sectors of the Brazilian economy ${ }^{\text {iii }}$, the survey of national literature did not show any work that uses the DEA methodology, in contrast to those found in the international literature ${ }^{\mathrm{iv}}$.

In this sense, this work represents a contribution to efficiency studies applied to the Brazilian construction industry.

\section{METHODOLOGY}

\subsection{General, technical and scale efficiency}

In the economic literature, "efficiency measures are usually represented by a function of frontiers constructed in the coordinate system, where efficient firms necessarily position themselves on the frontier ${ }^{v "}$ (Ferreira, Gonçalves and Braga, p.4, 2007).

Technical efficiency is characterized by the ability of the firm to produce as much product, given a level of inputs and a given technology. In graph 1 below, the technical efficiency is illustrated by the ratio $\mathrm{F}_{2} \mathrm{~F}_{0} / \mathrm{F}_{2} \mathrm{~F}_{3}$, to the CCR frontier (constant returns of scale) and $\mathrm{F}_{2} \mathrm{~F}_{0} / \mathrm{F}_{1} \mathrm{~F}_{2}$, to the $\mathrm{BCC}$ frontier (variable returns of scale) ${ }^{\mathrm{vi}}$.

On the other hand, the scale efficiency arises when the firm produces at an input level considered optimal (in Graph 1, the scale efficiency is represented by the ratio $\mathrm{F}_{1} \mathrm{~F}_{2} / \mathrm{F}_{3} \mathrm{~F}$ 2).The firm achieves overall efficiency when simultaneously operating, at technical and scale efficiency levels.

Graph 1 illustrates, through various points representing different combinations of inputs and outputs three types of efficiency described in the preceding paragraph. The firms represented by points $\mathrm{A}, \mathrm{B}, \mathrm{C}$ and $\mathrm{D}$ and $\mathrm{F} 1$ maximize the amount of product for a given input level, and hence, are located at the efficient frontier of production, technically appointed as efficient. Points $\mathrm{E}, \mathrm{F}_{\mathrm{o}}, \mathrm{F}_{2}$ and $\mathrm{G}$ are positioned below the frontier and, by analogy, do not have technical efficiency. Firm F o, for example, could, in the same amount of inputs used by firm $F_{2}$, generate the invoicing achieved by firm $F_{1}$ which is technically efficient. 


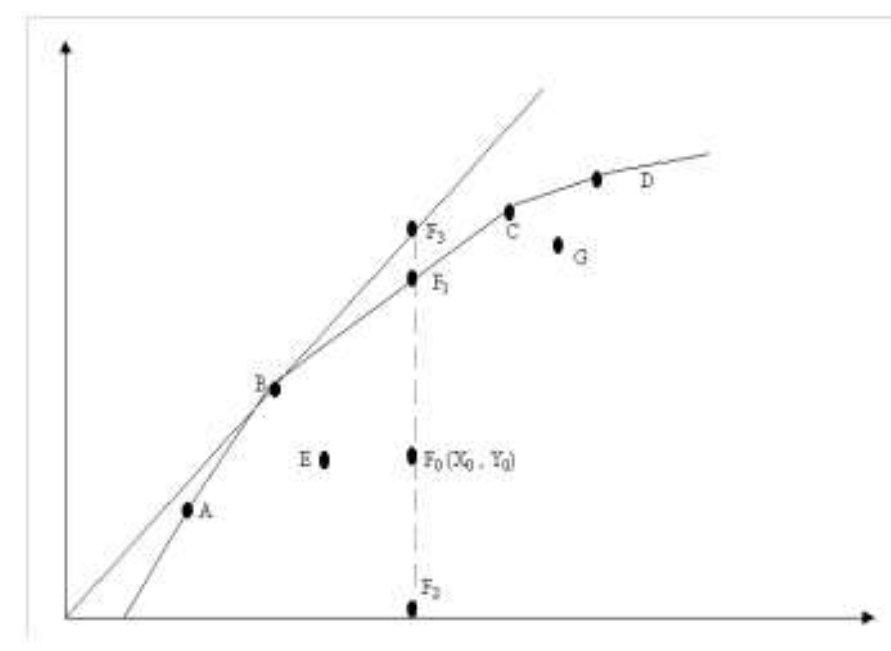

CHART 1 - GENERAL, TECHNICAL AND SCALE EFFICIENCY Source: Marinho and Cardoso (2007).

However, from the five companies said technically effective, the only one represented by $\mathrm{B}$ also has scale efficiency, since it is located at the point where the frontier to CCR tangents the BCC frontier.

\subsection{Data envelopment analysis (DEA)}

The data envelopment analysis (DEA) is basically a linear programming model that "attempts to comparatively analyze independent units, with regard to its operating performance, being able to incorporate multiple inputs and outputs to calculate efficiency" (Mac Dowell, p.6, 2007).

The $D E A$ is based on a set of observed data in several firms, called Decision Making Units - DMUs. The efficiency of each $D M U$ is evaluated, comparing it with a reference group consisting of other DMU with the same set of input and output. The frontier DMUs are called Pareto efficient, since it is not possible to improve some of its features without worsening the others.

An application of $D E A$ must be able to identify the causes and dimensions of relative inefficiencies for each $D M U$, provide an index of efficiency and set production targets that maximize the productivity of the evaluated units.

For Meza (1998), the implementation of a problem involving DEA covers three steps: definition and selection of the DMUs, selection of variables and, finally, choice and application of the model. 
Regarding the choice of the model, the CCR and $\mathrm{BCC}^{\text {vii }}$ are the best known and traditionally used in DEA modeling. While the former considers the constant returns to scale, the latter considers the variable returns to it, allowing the focus of the model to capture the effects along the production function resulting from changes in the production scale.

\subsection{DEA with constant returns to scale (CRS)}

The model proposed by Charnes, Cooper and Rhodes (1978) assumes the existence of $\mathrm{N} D M U s$ that use I inputs to produce $\mathrm{P}$ products. The index indicates the $\mathrm{i}$-th DMU for which the vectors xand represent the respective quantities of inputs and outputs. A nonparametric frontier is built and all firms should be above or below that frontier. The ratio between the weighted sum of the products and the weighted sum of inputs is maximized. The idea is to determine the "weightsth and that maximize the ratio of potential output and potential input for the i-th firm, where $\approx$ is a Px1 vector associated with the products and $\approx$ is an Ix1 vector of weights associated with inputs. Unknown quantities andkare calculated to maximize the efficiency of each $D M U$, according to the problem:

$$
\operatorname{Maxus}\left(u^{*} y_{k} / w^{*} z_{k}\right)
$$

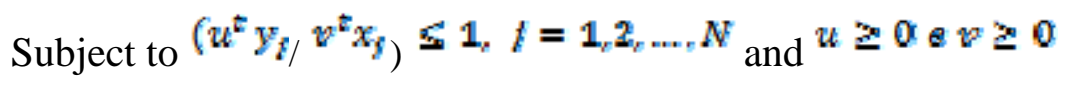

This formulation, however, presents an infinite number of solutions ${ }^{\mathrm{viii}}$. To get around it, the condition that $w^{2} z_{f}=1$ was imposed, leading to the following option:

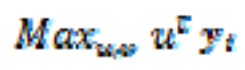

Subject to $v^{2} X_{1}=1$

$$
w^{2} y_{l}-v^{2} x_{l} \leq 0_{w} f={ }_{1,2, \ldots, \mathrm{N} \text { and }} u \geq 0 \notin v \geq 0
$$

The problem, however, presents a large number of constraints, which imposes difficulties for computing solutions. Using the duality property of linear programming, it is possible to establish an equivalent problem, but with fewer restrictions $(\mathrm{I}+\mathrm{P}<\mathrm{N}+1)$ :

$$
\operatorname{Min}_{\mathbb{R}, 0} \theta
$$




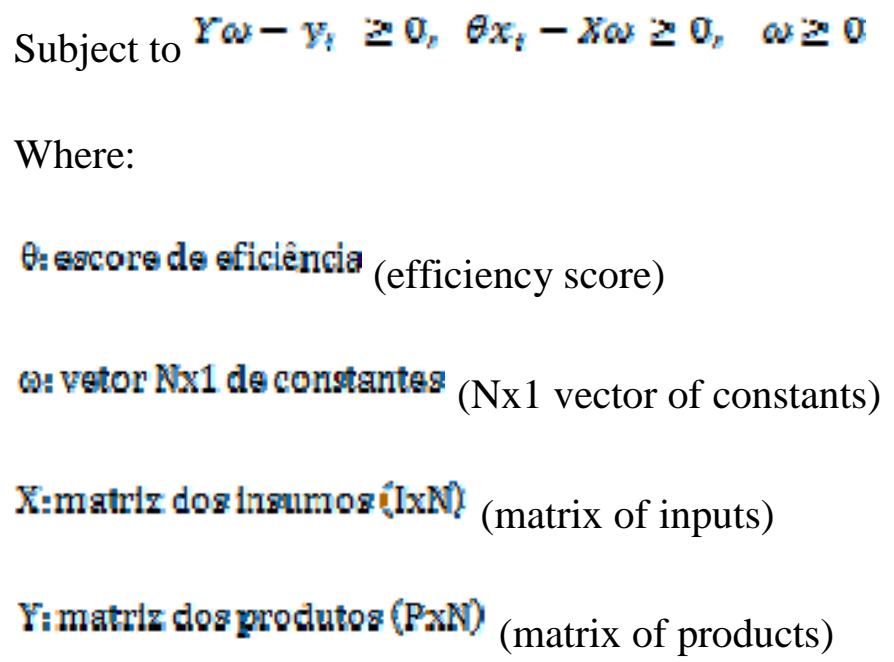

The problem is solved $\mathrm{N}$ times, once for each $D M U$. The efficiency score is given by $\theta$ and must meet the condition of $\theta \mathbb{K}$, where 1 indicates a point on the frontier and, consequently, a technically efficient firm.

\subsection{DEA with variable returns of scale (VRS)}

The assumption of constant returns of scale is appropriate only when all production units are operating at optimal scale. In practice, the existence of imperfect competition, government regulations and financial constraints, among other factors, may cause firms not to operate at its optimum level. In such case, one should choose the model of variable returns of scale, proposed by Banker, Charnes and Cooper (1984), in which the restriction of convexity $\mathbf{z}^{\mathrm{E}} \omega=1$ is added, such that:

$$
\operatorname{Mtn}_{\theta \rightarrow \infty} \theta
$$

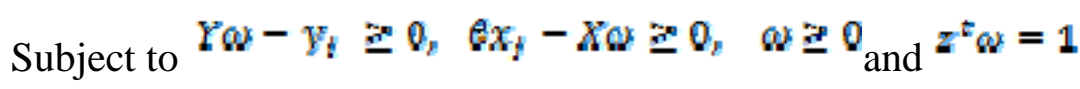

where $z=$ vetor wnithinto $N \times 1$ (unitary vector)

The resolution, via linear programming of the minimization process, described in Equation 4, returns, this way, values for the efficiency scores of the analyzed firms.

\subsection{Product-oriented DEA, and input-oriented DEA}

The measures of technical efficiency may assume both input and product orientation. The product-oriented $D E A$ defines the frontier seeking the maximum proportional increase of 
the product, without requiring more than a certain level of inputs. When input-oriented, the frontier seeks the maximum possible proportional reduction at the level of use of inputs, satisfying at least one given level of output.

Based on a given quantity of inputsrfor a given quantity of productsy, the technical inefficiency of the firm can be interpreted in two different ways. By assuming the orientation inputs, the distance between the firm and the production frontier represents the percentage by which the amount of all inputs must be reduced so that the production unit is fully efficient. On the other hand, the assumption of product orientation, the distance between the firm and the production frontier determines how the product can be expanded without changing the amount of inputs used (Carvalho e Marinho; p. 6, 2003) ${ }^{\mathrm{ix}}$.

\subsection{Multistage DEA}

Usually, the applications of data envelopment analysis are used to solve problems in a single stage. The use of multistage DEA, however, allows the analysis for panel data, assuming the hypothesis that the products resulting from a process can be used as inputs in the subsequent period.

According to Fowler et al (2006), one of the great advantages of the multistage DEA is that its emphasis on greater intensity to those inputs that are under managerial control, assigning different weights to them.

Lovell (2001) argues that the traditional data envelopment analysis allows the producer to ascertain whether or not the product is efficient, but that, before the interference of environmental forces, the results lose robustness. The analysis in multiple stages corrects the problem: at first, the efficiency scores are estimated ignoring environmental factors. In later stages, they are incorporated into the problem, generating results more consistent with reality.

\subsection{Malmquist Index and Total Factor Productivity}

The use of the Malmquist Index was highly influenced by the work of Caves, Christensen and Diewert (1982), who sought to assess the evolution of the productivity of each unit of production compared to the set of units to which it belongs.

For Figueiredo (2007), the Malmquist Index has important advantages over other measures of variation in total factor productivity (TFP). First, there is no need of prior definition of the production function, nor of indicating monetary values for inputs and 
products. Moreover, productivity can be decomposed into two sub-indices, the technical efficiency and technological progress. The former captures the productive deviations of the firm in relation to the technological frontier, and the latter, the deviations in relation to the frontier itself resulting from innovations.

Fare et al (1994) decomposed the variation of the technical efficiency in two components, the pure technical variation (regarding the frontier in an atmosphere of variable returns to scale) and in variations of scale efficiency, causing TFP oscillations to start depending on the three variables: pure and scale technical variations, and variations in the technological progress.

As discussed for DEA methodology for stacked data (pool), this index can also be built based on the orientation for the product or input. The distance function oriented by the product is defined as the maximum equi-proportional (radial) expansion of the product, given the vector of inputs. In orientation for inputs, optical is the maximum equi-proportional reduction of inputs, given the vector of product (Figueiredo, 2007).

The definition of the Malmquist index requires the existence of distance functions for two different periods, so that fluctuations in TFP can be computed. According to Coelli, O'Donnell and Battese (2005), assuming a given period $t$ as technology reference, the variation in TFP between two periods, with product orientation, can be defined as:

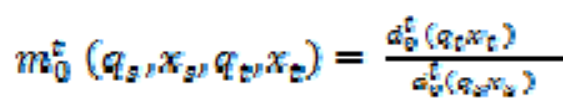

Equation 5 defines the index as the division of the maximum possible expansion of the product during period $s$, dagta and technology in period $t$, by the maximum possible expansion of the product in periodxand its related technology. The choice of the time of reference is arbitrary, and the results may vary depending on the selected period. In order to avoid the imposition of new restrictions to work around the problem, the Malmquist Index is usually defined as a geometric mean of the two scores of efficiency evolution, i.e.:

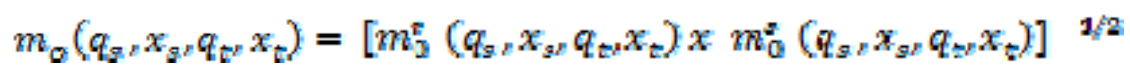

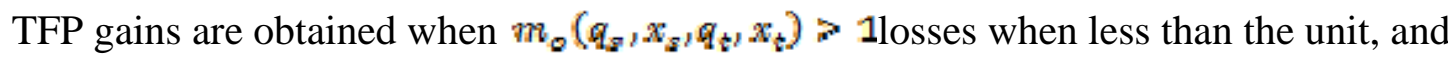
stagnation occurs when the score remains unchanged. 
The distance functions can be rearranged to show that they amount to the product of variation of technical efficiency by varying the technological progress, such that:

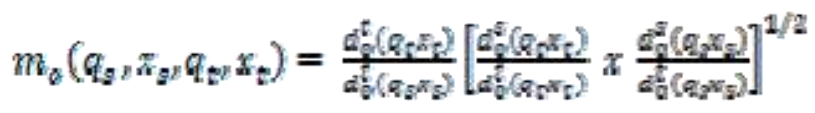

The first term on the right side of the equation represents the variation in technical efficiency, and the second term (in brackets) indicates the variation of technological progress, measured as the geometric average of technological changes over the two periods. Increments in the first component showed a recovery of production in relation to the efficient frontier (catching up), while increases in the second term, indicate technological innovation. Thus, productivity gains for a firm that already operates on the efficient frontier will only be possible with technological progress.

Breaking up the efficiency variation into pure and scale technical efficiency, as proposed by Fare et al (1994), the Malmquist Index may finally be described in its final form, according to the equation:

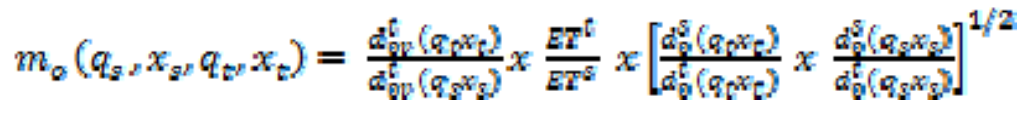

The first term on the right hand side represents the change in pure technical efficiency pure in environments with variable returns to scale, whose oscillations are captured up by the second term. The last term remains unchanged, and captures the variation regarding technological progress.

\section{DATABASE AND MODEL SPECIFICATION}

The database needs to present variables that work as input and other as products. Traditionally, capital and labor are the sources of inputs, which generate corporate revenue, representing the product. These variables were constructed from information provided by a traditional monthly journal of the constructive sector called The Contractor. Each year the journal publishes a differentiated issue entitled Contractor's Guide: The Great 500 of Civil Construction, which consolidates the information of the sector in the form of a ranking, which main criterion for placing is the company's annual gross revenue ${ }^{\mathrm{x}}$. 
In order to evaluate the behavior of construction companies throughout the economic cycle, the article deals with a time horizon of four years, registering rates from 2005 to 2008. Furthermore, the multiplicity of years allows the stacked data analysis, which provides much more consistent results than a simple evaluation of cross-section data.

Data of 185 companies were collected, but, since we are dealing with journal publication of voluntary participation, only 57 provided complete information during the sample period considered and, therefore, were able to compose the final sample. Because it is just a sample, the results of this study refer only to the analyzed firms, not representing a generalization for the construction industry as a whole ${ }^{\mathrm{xi}}$. The variables used for the data envelopment analysis are identified in Table 1.

TABLE 1 - VARIABLES USED FOR THE DEA

\begin{tabular}{|c|c|c|}
\hline VARIABLE & $\begin{array}{l}\text { FUNCTI } \\
\text { ON }\end{array}$ & DEFINITION \\
\hline Company name & $\begin{array}{l}\text { Identifica } \\
\text { tion }\end{array}$ & $\begin{array}{l}\text { It is the best known name of the company, which does not } \\
\text { always coincide with its corporate name. }\end{array}$ \\
\hline Gross Income - R\$ & Product & $\begin{array}{l}\text { Annual gross revenue of the company, as stated in the last } \\
\text { balance sheet. Values in deflated reais (base year }=2005 \text { ) }\end{array}$ \\
\hline $\begin{array}{l}\text { Number of employees } \\
\text { without higher education }\end{array}$ & Input & $\begin{array}{l}\text { Total number of employees - number of employees with } \\
\text { higher education at the date of balance sheet closure }\end{array}$ \\
\hline $\begin{array}{l}\text { Number of employees } \\
\text { with higher education }\end{array}$ & Input & $\begin{array}{l}\text { Number of employees with higher education on the date of } \\
\text { balance sheet closure }\end{array}$ \\
\hline Equipment & Input & $\begin{array}{l}\text { Physical quantity of equipment used by the firm to carry out } \\
\text { their activities }\end{array}$ \\
\hline
\end{tabular}

Own elaboration.

As is known, the choice of the envelopment to be calculated depends on the assumption about the returns to scale that the studied technology presents: either Constant Returns or Scale Variables (respectively "CRS" and "VRS"). Civil construction is subject to imperfect competition, government intervention, financial constraints and various other elements that do not allow them to work in an environment of constant returns. Thus, the proper choice would be the VRS model.

The choice between input or output orientation seems to be more subtle. In fact, Coelli (1996) states that the two models estimate the same frontier and, therefore, identify the same efficient DMUs. The difference only relies on the efficiency measures related to the 
inefficient DMUs. Companies working in the construction industry are private and seek to maximize profit. Thus, product orientation shows to be the most appropriate.

The existence of multiple periods allowed the construction of modeling of DEA in multistage, in which it is assumed that the product of the previous period may work as a productive input in the following period. The obtained results show greater consistency with respect to the cross-section analysis.

The gains of TFP were measured by the Malmquist Index oriented by the product and assuming it as being an environment with variable returns of scale. Thus, the variation of TFP was decomposed into variations of pure technical and scale efficiency, in addition to technological progress.

Armed with the necessary variables for the assembly of the database, as the methodology is defined, it becomes possible to rewrite the equations in its specific form:

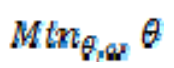

Subject to $Y \omega-y_{k} \geq 0_{n} \quad 6 x_{f}-X \omega \geq 0_{n} \quad \omega 0$ and $z^{2} \omega=1$ where:

$$
\begin{aligned}
& \mathrm{z}=\text { unit vector } \mathrm{Nx} 1 \\
& \mathrm{x}=\text { vector of inputs, where: } \\
& \mathrm{x} 1 \text { = equipment } \\
& \mathrm{x} 2=\text { employees without higher education } \\
& \mathrm{x} 3=\text { employees with higher education } \\
& \mathrm{y}=\text { product vector (deflated gross income) }
\end{aligned}
$$

The software selected for analysis was the DEAP 2.1 ${ }^{\text {xii }}$. We estimated four frontiers for the data of each cross-section of the sample and one for the pool ${ }^{x i i i}$. Furthermore, through the Malmquist Index, variations in the total factor productivity were measured.

Table 2 summarizes the minimum, maximum and average values for each input and the product used, measured along the four years of the sample. 
TABLE 2 - SUMMARY OF INPUTS AND PRODUCT

\begin{tabular}{|c|c|c|c|c|c|c|c|c|c|c|c|c|}
\hline \multirow{3}{*}{ Year } & \multicolumn{3}{|c|}{ Product } & \multicolumn{9}{|c|}{ Inputs } \\
\hline & \multicolumn{3}{|c|}{ Revenue - R\$ thousand } & \multicolumn{3}{|c|}{ Equipment } & \multicolumn{3}{|c|}{$\begin{array}{l}\text { Employees without } \\
\text { higher education }\end{array}$} & \multicolumn{3}{|c|}{$\begin{array}{l}\text { Employees with } \\
\text { higher education }\end{array}$} \\
\hline & $\min$ & $\max$ & average & $\min$ & $\max$ & average & $\min$ & $\max$ & average & $\min$ & $\max$ & average \\
\hline 2005 & 8221 & $1,206,359$ & 143,032 & 8 & 2,226 & 283 & 32 & 8700 & 1117 & 8 & 849 & 84 \\
\hline 2006 & 14,243 & $2,348,704$ & 281,372 & 3 & 3307 & 333 & 59 & 8801 & 1229 & 8 & 970 & 101 \\
\hline 2007 & 16,780 & $3,054,387$ & 283,008 & 10 & 3439 & 355 & 40 & 18,185 & 1691 & 6 & 1259 & 150 \\
\hline 2008 & 9479 & $2,575,213$ & 234,068 & 10 & 3189 & 360 & 81 & 35,928 & 2247 & 5 & 3544 & 227 \\
\hline
\end{tabular}

Data show significant variations in the level of revenue of the companies, as well as the amount of available inputs for each of them. Moreover, despite the contraction in the average revenue of 2008 , the average amount of inputs - especially the labor factor - increased considerably in the same year. An increase of $170 \%$ on average use of employees with higher education has been registered, a trend that may continue in view of increased competition in the sector, the expansion of the volume and forms of investment, the greater rigidity in the quality control of works and the complexity of internal structures, which require more qualified personnel.

In 2008, Camargo Correa, a leader in revenue, which also used of the workforce with higher education at the most, while Queiroz Galvao, third in revenue, held the top spot in the use of workers without higher education and in the possession of equipment. In contrast, Vial, penultimate in revenue, was the firm which least used employees with higher education, and Zita, $45^{\text {th }}$ in revenue, took the lowest place on the list as regards to the use of capital inputs.

\section{RESULTS}

\subsection{Technical and Scale Efficiency}

The pure technical and scale efficiency scores were estimated for the 57 construction companies over the four sampling periods, through multistage DEA methodology. The results are summarized in Table 3.

In all years, at least one firm has obtained the maximum score of technical or scale efficiency. Furthermore, the average score of scale efficiency was considerably higher than that of technical efficiency between 2005 and 2008. 
TABLE 3 - SUMMARY OF TECHNICAL AND SCALE EFFICIENCIES

\begin{tabular}{|c|c|c|c|c|c|c|c|c|c|c|}
\hline \multirow{2}{*}{ Year } & \multicolumn{5}{|c|}{ Technical Efficiency } & \multicolumn{5}{|c|}{ Scale Efficiency } \\
\hline & $\min$ & $\max$ & average & median & st. dev. & $\min$ & $\max$ & average & median & devspad \\
\hline 2005 & 0.067 & 1 & 0.373 & 0.272 & 0.253 & 0.318 & 1 & 0.759 & 0.791 & 0.204 \\
\hline 2006 & 0.129 & 1 & 0.572 & 0.539 & 0.283 & 0.27 & 1 & 0.750 & 0.750 & 0.182 \\
\hline 2007 & 0.08 & 1 & 0.486 & 0.412 & 0.277 & 0.287 & 1 & 0.722 & 0.742 & 0.199 \\
\hline 2008 & 0.059 & 1 & 0.338 & 0.290 & 0.226 & 0.185 & 1 & 0.701 & 0.733 & 0.217 \\
\hline
\end{tabular}

Own elaboration.

The maximum technical efficiency (score $=1$ ) was found in four of the 57 companies in 2005, nine the following year and seven in 2007. In the last year of the sample, only Vial, from São Paulo, showed to be fully efficient. Andrade Gutierrez and Fidens had 100\% efficiency in some of the years analyzed (both in 2006).

The lowest score of technical efficiency in 2005, was of the Pelotense, Rio Grande do Sul. On the next two years, the Consita from Minas Gerais was the most inefficient among the assessed companies, with scores of 0.129 and 0.08 , respectively. In the last year, the Minas Gerais company gave way to the Ebisa from Bahia, with a score of 0.059 , the lowest of four years.

Overall, the average score of technical efficiency of domestic firms declined between the first and last year examined ${ }^{\text {xiv }}$ (Graph 2).

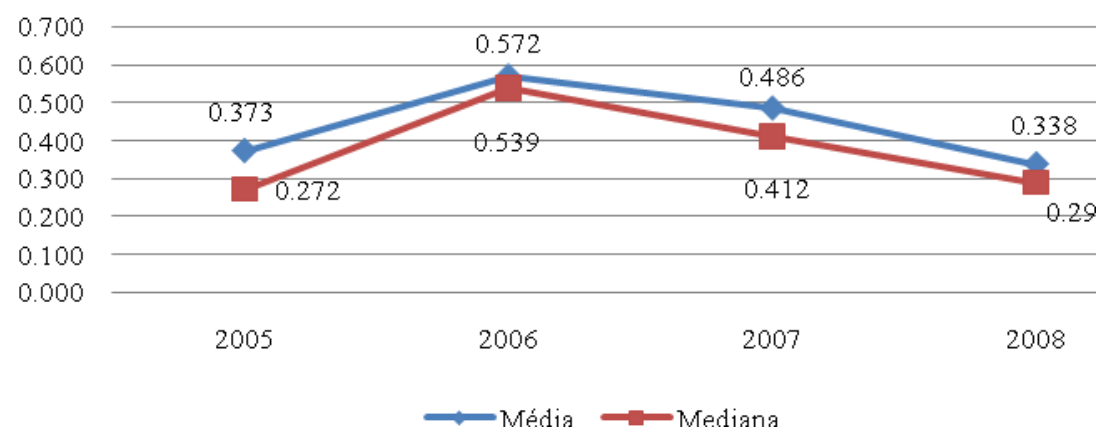

GRAPH 2 - EVOLUTION OF TECHNICAL EFFICIENCY (NATIONAL AVERAGE) Note: Own elaboration.

Individually, some firms have excelled in the ability to correct internal inefficiencies over the years and come close to the efficient frontier (Graph 3). In contrast, there are those that started with high scores of technical efficiency in 2005, but were not able to keep them for the next years (Graph 4). 


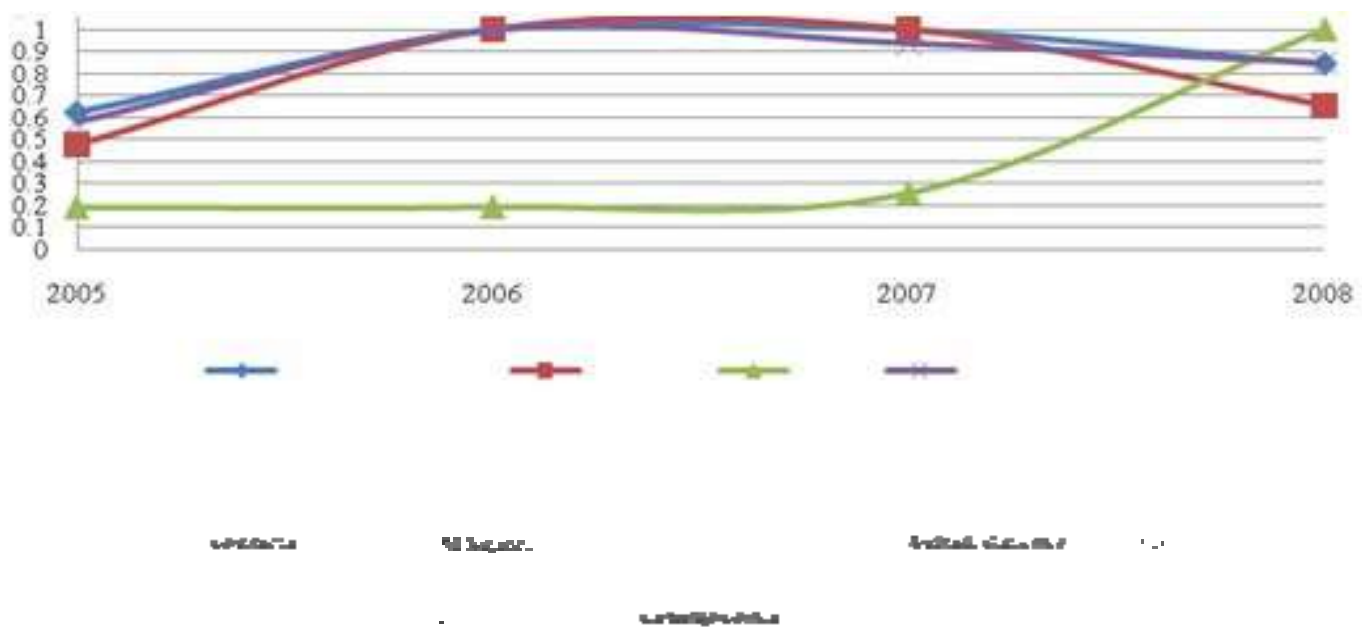

GRAPH 3 - MAJOR HIGH SCORES (ET)

Note: Own elaboration.

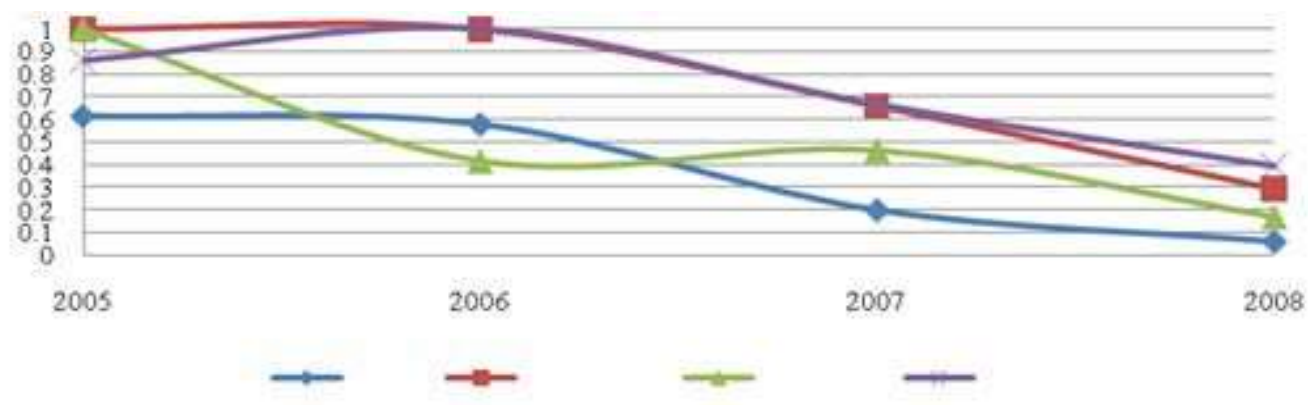

GRAPH 4 - MAJOR DECLINES IN SCORES (ET)

Note: Own elaboration.

The most significant rise was from Vial, in Sao Paulo, which occupies the last position in average annual revenues. M. Bigucci, also from São Paulo and the fifth smallest in revenue, reported the sharpest decline, ending the year 2008 with a score of 0.29 , lower than the national average.

As for the returns to scale, $91.2 \%$ of firms, on average, operated with variable returns to scale. Among these, there was a predominance of construction companies operating in diminishing returns, i.e., above the range considered optimal (Table 4), in which revenue growth is given at increasing costs (decreasing when in increasing returns to scale).

TABLE 4 - RETURNS TO SCALE

\begin{tabular}{c|c|c|c|c}
\hline Returns & $\mathbf{2 0 0 5}$ & $\mathbf{2 0 0 6}$ & $\mathbf{2 0 0 7}$ & $\mathbf{2 0 0 8}$ \\
\hline Constants & 7 & 3 & 4 & 6 \\
\hline Decreasing & 39 & 47 & 45 & 46 \\
\hline Growing & 11 & 7 & 8 & 5 \\
\hline
\end{tabular}

Note: Own elaboration. 
Since the magnitude of revenue varies considerably between the firms analyzed, scores of technical and scale efficiency per revenue strata, in order to create more homogeneous samples. Four categories were created: revenue exceeding R\$ 500 million, revenues between $\mathrm{R} \$ 100$ and $\mathrm{R} \$ 500$ million, between $\mathrm{R} \$ 40$ and $\mathrm{R} \$ 100$ million and less than $\mathrm{R} \$ 40$ million. The division was based on the average annual revenues between 2005 and 2008 (Table 5).

TABLE 5 - STRATA OF REVENUE

\begin{tabular}{c|c|c}
\hline Sector & Number of Firms & Average Revenue \\
\hline exceeding R \$ 500 million & 4 & $395,184.61$ \\
\hline $\mathrm{R} \$ 100-500$ million & 20 & $172,094.69$ \\
\hline $\mathrm{R} \$ 40-100$ million & 13 & 47973.65 \\
\hline less than R\$ 40 million & 20 & 24061.68 \\
\hline
\end{tabular}

Note: Own elaboration

The construction companies' higher stratum were more technically efficient in all years, with an annual average of $82.1 \%$, above the cut-off rate considered optimal (80\%). Companies with revenues less than $\mathrm{R} \$ 40$ million were located far from the efficiency frontier, with an average score of 28.9\% annually. Between 2006 and 2008, scores of technical efficiency for the four strata declined considerably. The year 2008 was marked by the global economic crisis, which contracted the economy and the construction industry. Still, firms in the upper stratum were able to improve the efficiency compared to 2005, which was not observed in the three lower strata $(\text { Graph } 5)^{\mathrm{xv}}$.

The results indicate considerable differences in efficiency scores based on the level of revenue. Furthermore, they evidenced that the construction industry is characterized by imperfect competition, in which financial constraints, project limitations and zoning and strong competition in bidding, among other factors, inhibit the performance of smaller firms.

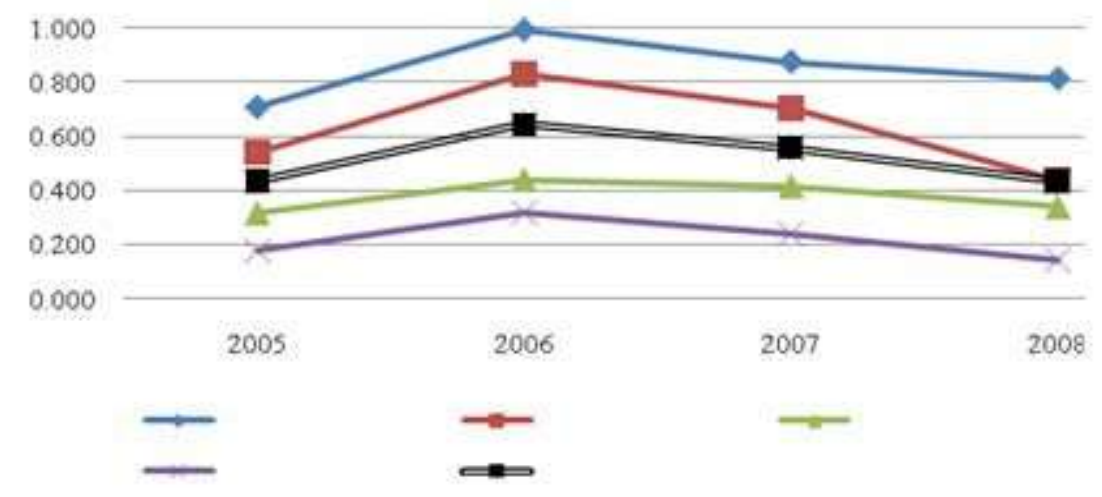

GRAPH 5 - AVERAGE TECHNICAL EFFICIENCY PER LEVELS OF REVENUE Note: Own elaboration. 
In contrast, the scale efficiency scores indicate that firms in the lower strata are, on average, those that operate closer to the optimal scale of production (Table 6) ${ }^{\mathrm{xvi}}$. Due to the fact that they have smaller plants, it is possible that firms with lower revenue are able to allocate its inputs more accurately. As for those with high revenue, with activities and branches scattered across several federal units and performing large works, may have greater difficulty in managing and finding the correct way to allocate their production inputs.

TABLE 6 - AVERAGE EFFICIENCY OF SCALE BY FIRM SIZE

\begin{tabular}{|c|c|c|c|c|c|}
\hline Sector & 2005 & 2006 & 2007 & 2008 & Average \\
\hline $\begin{array}{l}\text { exceeding } \mathrm{R} \$ 500 \\
\text { million }\end{array}$ & 0.354 & 0.387 & 0.348 & 0.287 & 0.342 \\
\hline $\mathrm{R} \$ 100-500$ million & 0.693 & 0.658 & 0.616 & 0.607 & 0.643 \\
\hline $\mathrm{R} \$ 40-100$ million & 0.859 & 0.798 & 0.785 & 0.744 & 0.795 \\
\hline less than $\mathrm{R} \$ 40$ million & 0.842 & 0.883 & 0.862 & 0.851 & 0.859 \\
\hline
\end{tabular}

Note: Own elaboration.

In addition to the lower revenue than the one designed according to the level of inputs used, $65 \%$ of firms, on average, presented some floats in the three available inputs (Table 7), i.e., could be made more efficient if they contracted the excessive amount for the optimal projected amount. Maintaining a staff (without higher education) exceeding the necessary is the main factor in respect to the incorrect allocation of firm resources, and such inefficiency is present in almost half of the assessed construction companies ( $47.4 \%$ on average).

TABLE 7 - NUMBER OF FIRMS WITH FLOATS

\begin{tabular}{|c|c|c|c|c|}
\hline Input & 2005 & 2006 & 2007 & 2008 \\
\hline Equipment & 2 & 1 & 4 & 5 \\
\hline Employees without higher education & 30 & 25 & 22 & 3 \\
\hline Higher Education & 6 & 2 & 9 & 11 \\
\hline
\end{tabular}

Note: Own elaboration.

This finding may be corroborated by the high social charges levied upon the construction worker, which can reach the level of $177 \%$ over the constant starting salary on the payroll ${ }^{\mathrm{x} v i i}$. Thus, the maximization of revenue is hampered facing a quite costly productive input for firms, which explains part of the inefficiency of those. Thus, the overall efficiency of the firm depends on its ability to maximize revenue and to allocate production inputs properly and avoid floats, which is not always done correctly. 
Scopus, for example, of which technical efficiency scores are reported in Graph 4, showed a significant drop in technical efficiency between 2005 and 2008 (Table 8).The company has expanded its available inputs, but the generated revenue was much less than projected.

TABLE 8 - SCOPUS: ORIGINAL AND PROJECTED VALUES FOR INPUT AND OUTPUT

\begin{tabular}{c|c|c|c|c|c|c|c|c|c|}
\hline & \multicolumn{4}{c}{2005} & \multicolumn{5}{c}{2008} \\
\hline \multirow{2}{*}{ Input / Product } & \multicolumn{4}{c}{ Technical Efficiency $=\mathbf{0 . 8 6}$} & \multicolumn{3}{c}{ Technical Efficiency = 0.395 } \\
\cline { 2 - 10 } & Original & $\begin{array}{c}\text { Radial } \\
\text { Mov. }\end{array}$ & Float & $\begin{array}{c}\text { Projected } \\
\text { Value }\end{array}$ & Original & $\begin{array}{c}\text { Radial } \\
\text { Mov. }\end{array}$ & Float & $\begin{array}{c}\text { Projected } \\
\text { Value }\end{array}$ \\
\hline Equipment & 10 & 0 & 0 & 10 & 14 & 0 & 0 & 14 \\
\hline Employees w/h* & 70 & 0 & 0 & 70 & 217 & 0 & 0 & 217 \\
\hline Employees n/h * & 10 & 0 & 1 & 9 & 17 & 0 & 3 & 14 \\
\hline Revenue & 38,107 & 6202 & 0 & 44,309 & 44,472 & 68,105 & 0 & 112,577 \\
\hline
\end{tabular}

* W / h: with higher education; $\mathrm{n} / \mathrm{h}$ : no higher education

Note: Own elaboration.

In contrast, Andrade Gutierrez was able to make better use of the available inputs to increase revenues, although it stood, at the end of 2008, behind the projected level. The firm increased the number of employees with and without higher education and reduced capital investment. Despite the increase in the technical efficiency score, the firm, with the new composition of raw materials, lost in scale efficiency (Table 9).

\section{TABLE 9 - ANDRADE GUTIERREZ: ORIGINAL AND PROJECTED VALUES FOR INPUT AND} OUTPUT

\begin{tabular}{|c|c|c|c|c|c|c|c|c|}
\hline \multirow{3}{*}{ Input / Product } & \multicolumn{4}{|c|}{2005} & \multicolumn{4}{|c|}{2008} \\
\hline & \multicolumn{4}{|c|}{$\begin{array}{c}\text { Technical Efficiency }=0.576 \\
\text { Scale }=0.404(\text { DRS })\end{array}$} & \multicolumn{4}{|c|}{$\begin{array}{c}\text { Technical Efficiency }=0.847 \\
\text { Scale }=0.323(\text { DRS })\end{array}$} \\
\hline & Original & $\begin{array}{l}\text { Radial } \\
\text { Mov. }\end{array}$ & Float & $\begin{array}{l}\text { Projected } \\
\text { Value }\end{array}$ & Original & $\begin{array}{c}\text { Radial } \\
\text { Mov. }\end{array}$ & Float & $\begin{array}{c}\text { Projected } \\
\text { Value }\end{array}$ \\
\hline Equipment & 2053 & 0 & 0 & 2053 & 1971 & 0 & 0 & 1971 \\
\hline Employees w/h* & 7863 & 0 & 2250 & 5613 & 11,640 & 0 & 0 & 11,640 \\
\hline Employees $\mathrm{n} / \mathrm{h}$ * & 517 & 0 & 0 & 517 & 1315 & 0 & 320 & 995 \\
\hline Revenue & $1,016,140$ & 746,649 & 0 & $1,762,789$ & $2,142,636$ & 386,877 & 0 & $2,529,513$ \\
\hline
\end{tabular}

\footnotetext{
* W / h: with higher education; $\mathrm{n} / \mathrm{h}$ : no higher education
}

Note: Own elaboration. 
After discussing the parameters, it becomes possible to present the overall ranking of average technical efficiency of construction firms, whose criterion of analysis is based solely on the ordering of the highest to lowest score. Camargo Corrêa, Christian Nielsen, Andrade Gutierrez, Construtora OAS and Queiroz Galvão are the five most effective.

Camargo Correa was the company which stood nearest to the efficient frontier, with an average score of 0.8513 .The last five positions were occupied by three companies from Rio Grande do Sul and two from Minas Gerais (Viero, Sital, Ernesto Woebcke, Pelotense and Consita).

\subsection{Total Factor Productivity}

The DEA-Malmquist methodology was used to capture the variations in technical, technology and scale efficiencies over the period, as well as differences in the Total Factor Productivity (TFP).Values above unit indicate that there was an increase in the Index, decrease when lower and unchanged when equal to the unit.

The results of technological variations (TECH), pure technical efficiency (PTE), scale efficiency (SCALE) and TFP are summarized in Table 10, for the average results for the period between 2005 and 2008.

TABLE 10 - SUMMARY OF MALMQUIST DEA- AVERAGE 2005-2008

\begin{tabular}{c|c|c|c|c}
\hline \multicolumn{1}{c|}{ Data } & TECH & ETP & Scale & PTF \\
average & 0.902 & 0.984 & 1.049 & 0.928 \\
\hline minimum & 0.634 & 0.492 & 0.724 & 0.469 \\
\hline maximum & 1.085 & 1.620 & 1.317 & 1.476 \\
\hline devspad & 0.100 & 0.189 & 0.110 & 0.168 \\
\hline
\end{tabular}

Note: Own elaboration.

On average, both technological progress and the pure technical efficiency had a slight drop, which explains the decline in TFP between 2005 and 2008. The average variation of the indicators, captured every year, is summarized in Table 11 .

TABLE 11 - ANNUAL AVERAGE VARIATION OF THE INDICATORS

\begin{tabular}{r|c|c|c|c}
\hline Indicator & $\mathbf{2 0 0 5 - 2 0 0 6}$ & $\mathbf{2 0 0 6 - 2 0 0 7}$ & $\mathbf{2 0 0 7 - 2 0 0 8}$ & Mean $\Delta$ \\
\hline TECH & 1.286 & 1.301 & 0.439 & 0.902 \\
\hline ETP & 1.123 & 0.738 & 1.148 & 0.984 \\
\hline Scale & 1.144 & 0.802 & 1.258 & 1.049 \\
\hline PTF & 1.651 & 0.769 & 0.630 & 0.928 \\
\hline
\end{tabular}

Note: Own elaboration. 
After the significant increase between 2005 and 2006, TFP has declined significantly over the two following years. In 2006-2007, the loss was associated with loss of technical and scale efficiency, while in 2007-2008, the sharp contraction of the technological progress was largely responsible for the loss of $37 \%$ in factor productivity.

The information obtained allowed the generation of a new ranking, ordering firms based on higher gains (or smaller losses) on total factor productivity, decomposing it based on the variation of pure technical and scale efficiency, as well as oscillations of the technological progress. The greatest drop in PTF was recorded for Ebisa, mainly due to the sharp drop in technical efficiency. Christian Nielsen, from Rio de Janeiro, also experienced sharp decline in TFP (third most severe), but unlike Ebisa, the loss of productivity factors occurred because the firm did not keep pace with the technological progress. The technical and scale efficiencies of such remained unchanged in time.

Pedrasul occupied the $53^{\text {rd }}$ spot in terms of technological progress. However, variations in pure technical and scale efficiency were sufficiently strong to enable gains of $21.7 \%$ in TFP.

From the fifty-seven companies in the sample, only twelve managed to register gains from the technological progress, and nine of them are located in the two lowest income strata. The ICEC was the greatest beneficiary, with gains of $8.5 \%$, followed by Toda do of Brasil and Collem Mohallem, with gains of $7.5 \%$ and $6.7 \%$ respectively.

When classified by revenue strata, it was found that PTF had losses in all four levels. The smallest drop (-4.3\%) occurred among the firms with highest revenue, while the greatest one $(-8.8 \%)$ was from those from the lower strata. In all strata gains of scale were recorded, and the most significant companies in the second level (9.4\%) were those with the most gain, in which we also found the greatest losses in the technological progress $(-11.6 \%)$.Only firms in the upper stratum maintained the technical efficiency, while the variation was negative for the other levels. Unlike the conclusions obtained for the technical efficiency scores per revenue strata (Graph 5), it is not possible to verify a strong relationship between variation in TFP and the stratum in which the construction company is situated.

\section{DISCUSSION AND CONCLUSION}

The civil construction sector came out from a strong stagnation, since the 80 s to current mid-decade, in order to assume an important role in the Brazilian economic growth. The demand for infrastructure, the government programs and the availability of credit which began to be directed to the civil construction sector intensified the pace of business activity. 
The growth, however, was not accompanied by improvements in efficiency. Based on our sample, the average technical efficiency score for the period was 0.433 and has shown a downward trend since 2006.Most construction companies operated in an environment of variable returns to scale, with a predominance of decreasing returns. The results indicate that, on average, firms face internal organizational difficulties and inputs, available outside the range considered optimal, are not fully utilized for the generation of revenue.

Moreover, the performance of firms was not homogeneous among different income strata. There are indications of positive relationship between the volume of revenue and the technical efficiency score. In contrast, the highest-revenue firms were those with grater difficulties to allocate the inputs correctly, recording the lowest scores of scale efficiency.

In general, the different scores obtained on the basis of revenue seem to serve as support to the thesis that the construction sector is characterized by imperfect competition and that external forces, such as government programs, funding sources, business reputation and legislation, among others, affect the performance of construction companies.

Unqualified workforce was primarily responsible for the floats of productive inputs in firms and explains part of the inefficiency of those. Indeed, labor and social security costs not only for civil construction but for Brazil as a whole - are costly and often exceed the $100 \%$ barrier. The replacement of unskilled workers by those with higher qualifications or by capital investment, contributing to increase firm productivity, may be a good alternative for the civil construction.

While the sector continues to expand, the trend is that there is mobility of workforce, in which workers dismissed from a firm that increased capital investments may be reemployed in another which has lower technological resources. The contraction of the sector will significantly increase unemployment, which explains the massive government investment in infrastructure and housing throughout the territory.

Moreover, in our sample, the total factor productivity in the 2005-2008 period, decreased by $7.2 \%$, mainly due to the negative variation in technological progress. However, the behavior of TFP fluctuated significantly over the period.

Between 2005 and 2006, there were gains in technical and scale efficiency, as well as technological innovation, resulting in an increase of $65.1 \%$ in TFP. The reasons are not difficult to observe. First, the industry remained stagnant until 2004, when it slowly began to gain strength. So it was natural that, after growth was resumed, firms could take advantage of the technological innovations to better utilize their productive inputs. The year 2006 was also 
marked by federal and state elections, which traditionally stimulate the opening of construction sites across the country. In addition, for real estate firms, the text of Law 9514 of 1997, which established the chattel mortgage, was expanded, ensuring greater contract stability for the firms of the sector.

In the period of 2006-2007, our results suggest that firms continued recovering its outdated technology, but the gains were insufficient to compensate losses in pure technical and scale efficiency scores and TFP fell by $23.1 \%$. During this period, the IPOs above market value, the high real estate financing ${ }^{\mathrm{xiii}}$ and inflated production inputs ${ }^{\mathrm{xix}}$ were common, which accentuated the organizational inefficiencies.

Finally, the period of 2007-2008 was marked by strong global economic crisis, which restricted credit and contracted the construction sector. However, it is possible to say that the crisis has forced companies to restructure internally, cut floats and better organize their inputs and processes, which led to a slight increase in technical and scale efficiency. The negative variation of TFP in the period can be attributed, therefore, to the high loss of technological progress.

It is worth noting that the country will host the World Cup in 2014, and the city of Rio de Janeiro, the 2016 Olympics. Until then, the construction sector will be highlighted and the trend is of significant increase in the product generated by the sector.

Given the optimistic scenario, competition in the sector is expected to rise rapidly, and firms will be forced to innovate technologically, correctly allocate the inputs and optimize their use, if they want to remain competitive. Within this context, the concerns are renewed: large companies should continue enjoying monopolistic advantages, placing himself in a position of superiority in relation to minors, even efficient, may be unable to sustain the market. The wave of mergers, acquisitions and capital opening should be resumed. For smaller firms, but with a high level of technical efficiency and good technological standards, the opportunity of being acquired at a fair price by major construction companies seems to emerge as a major attraction of the market.

\section{REFERENCES}

ARCOVERDE, F.; SOUSA, M.; TANNURI-PIANTO, M. Fronteiras de eficiência estocásticas para as empresas de distribuição elétrica no Brasil: uma análise de dados de painel. Estudos Econômicos, São Paulo, v. 39, n. 1, p. 221-247, 2009.

BANKER, R. D.; CHARNES A.; COOPER W. W. Some models for estimating technical and scale inefficiencies in data envelopment analysis. Management Science, v. 30, n. 9, 1984. 
BARRETO, A. F. D.; MARINHO, E.; OLIVEIRA, T. Abertura econômica e o desempenho da produtividade da indústria brasileira de1985/1996: uma abordagem utilizando o índice de Malmquist e a teoria da fronteira estocástica. In: BARRETO, Flávio A.F.D. Produtividade: teoria e evidências para o Brasil e a América Latina. Fortaleza: CAEN, Edições UFC, 2006. Cap. 4, p. 87-114.

BOLETIM informativo: retrospectiva - fatos marcantes de 2007. Bovespa, n.115, 2008. Disponível em: 〈http://www.acionista.com.br/bovespa/110108_boletim_novomercado.pdf $>$. Acesso em: 17 nov. 2009.

CARVALHO, R.; MARINHO, E. Transformações estruturais, variações na eficiência técnica e produtividade total dos fatores no setor agrícola dos países sul-americanos - 1970 a 2000. In: ENCONTRO NACIONAL DE ECONOMIA DA ASSOCIAÇÃO NACIONAL DOS CENTROS DE PÓS-GRADUAÇÃO EM ECONOMIA, 31., 2003, Anais... Niterói: Anpec, 2003.

CAVES, D.; CHRISTENSEN, L.; DIEWERT, E. Multilateral comparisons of output, input and productivity using superlative index number. The Economic Journal, v. 92, n. 365, p. 73-86, Mar. 1982.

CHARNES, A.; COOPER, W.; RODES, E. Measuring the efficiency of decision making units. European Journal of Operational Research, v. 2, n. 6, p. 429-444, 1978.

CHAU, K.; WANG, Y. Factors affecting the productivity efficiency of construction firms in Hong Kong. In: CIB TG INTERNATIONAL CONFERENCE, 23., Oct. 2003, Hong Kong.

COELLI, T. et al. An introduction to efficiency and productivity analysis. New York: Springer, 2005.

COOPER, W.; SIEFORD, L.; TONE, K. Data envelopment analysis: a comprehensive text with models, applications, reference and DEA-solver software. Norwell: Kluwer Academic, 2000 .

DEBREU, G. The coefficient of resource utilization. Econométrica, v. 19, n. 3, p. 273-292, jul. 1951.

DELGADO, V. Eficiência das escolas públicas estaduais de Minas Gerais: considerações acerca da qualidade a partir da análise dos dados do SICA e do SIMAVE. 2007. $157 \mathrm{f}$.

Dissertação (Mestrado em Economia) - Centro de Desenvolvimento e Planejamento Regional da Faculdade de Ciências Econômicas, Universidade Federal de Minas Gerais, Belo Horizonte, 2007.

DNIT. Departamento Nacional de Infra-Estrutura de Transportes. Programa de Aceleração do Crescimento: PAC prevê $\mathrm{R} \$ 503,9$ bilhões em investimentos nos próximos quatro anos. Disponível em: http://www.dnit.gov.br/menu/pac/pac_inicio. Acesso em: 17 nov. 2009.

EDVARDSEN, D. Efficiency of Norwegian construction firms: four essays in the measurement of production efficiency. School of Economics and Commercial Law, Goteborg University. 2003. 
FARE, R. et al. Productivity growth, technical progress, and efficiency change in industrialized countries. American Economic Review, v. 84, n. 1, p. 66-83, 1994.

FARRELL, M. J. The measurement of productive efficiency. Journal of the Royal Statistical Society, v. 120, n. 3, p. 253-290, 1957.

FERREIRA, M.; GONÇALVES, R.; BRAGA, M. Investigação do desempenho das cooperativas de crédito de Minas Gerais por meio da análise envoltória de dados (DEA). Economia Aplicada, v. 11, n. 3, p. 425-445, 2007.

FIGUEIREDO, A. T. Mensuração e análise da produtividade total dos fatores agregada no Brasil: aplicação da abordagem de bootstrap ao índice de Malmquist. 2007. 115 f. Dissertação (Mestrado em Economia) - Programa de Pós-Graduação em Economia, Universidade Federal do Rio Grande do Sul, Porto Alegre, 2007.

FOWLER, J. et al. Multi-stage DEA as a measurement of progress in environmentally benign manufacturing. Flexible automation and intelligent manufacturing. In: FLEXIBLE AUTOMATION AND INTELLIGENT MANUFACTURING, FAIM2006, Limerick, Irlanda.

JAN, J. Construction site productivity measurement: selection, application and evaluation of methods and measures. 1996. $207 \mathrm{f}$. Doctoral thesis - Department Civil and Mining Engineering / Construction Management, Lulea University of Technology, 1996. Disponível em: <http://epubl.luth.se/avslutade/0348-8373/185/index-en.html>. Acesso em: 3 Mar. 2009.

LOVELL, K. Future research opportunities in efficiency and productivity analysis. Efficiency Series Paper 01/2001. Universidad de Oviedo, Departamento de Economía. Disponível em: 〈http://www.unioviedo.es/oeg/ESP/esp0101.pdf>. Acesso em: 3 nov. 2009.

MAC DOWELL, F. Uma aplicação do método de data envelopment analysis - DEA para medir a eficiência operacional dos terminais de contêineres. Revista Eletrônica de Gestão de Negócios - Egesta, v. 3, n. 3, p. 105-128, 2007.

MARINHO, A.; CARDOSO, S. Avaliação da eficiência técnica e da eficiência de escala do sistema nacional de transplantes. Instituto de Pesquisa Econômica Aplicada - IPEA, texto para discussão, n.1260, Rio de Janeiro, fev. 2007.

MELLO, E. Produtividade total dos fatores, mudança técnica, eficiência técnica e eficiência de escala na indústria brasileira 1996-2000. 2003. 104 f. Tese (Mestrado em Economia) - Centro de Desenvolvimento e Planejamento Regional da Faculdade de Ciências Econômicas, Universidade Federal de Minas Gerais, Belo Horizonte, 2003.

MEZA, L. A. Data envelopment analysis na determinaçao da eficiência dos programas de pós-graduação da Coppee - UFRJ. Dissertação (Mestrado em Engenharia de Produção). Universidade Federal do Rio de Janeiro, 1998.

NATIONAL STEERING COMMITTEE FOR INNOVATION IN CONSTRUCTION (NSCIC). The construction industry as a place to invest. Apresentação do NSCIC's Second Canadian Construction Innovation Forum: Building a Strategy for Tomorrow, Canada, 2003. 
NGUYEN, K.; GIANG, T. Efficiency of construction firms in Vietnam. Munich Personal RePec Archive, paper n. 968, p. 42-58, Jan. 2005. Disponível em <http://mpra.ub.unimuenchen.de/2872>. Acesso em: 23 fev. 2009.

500 GRANDES DA CONSTRUÇÃO. O Empreiteiro, São Paulo, ano XLVI, n.466, julho. 2008.

ROCHA, F.; SOUSA, I. Cálculo da produtividade da indústria brasileira usando o método de fronteiras estocásticas: 2000-2006. Estudos Febrafarma, 2007.

SAMPAIO, L.; RAMOS, F.; SAMPAIO, Y. Privatização e eficiência das usinas hidrelétricas brasileiras. Economia Aplicada, v. 9, n. 3, p. 465-480, 2005.

SAMPAIO, B.; SAMPAIO, Y. Influências políticas na eficiência das empresas de saneamento brasileiras. Economia Aplicada, v. 11, n. 3, p. 369-386, 2007.

SHAHA, A.; RAVISANKAR, T. Rating of Indian commercial banks: a DEA approach. European Journal of Operational Research, n. 124, p. 187-203. 2000.

SHEPARD, R.W. Theory of cost and production functions. Princeton: Princeton University Press, 1953.

SECOVI-SP- Sindicato da Habitação de São Paulo. Balanço Imobiliário 2008. Disponível em http://www.secovi.com.br/pesquisa/balanco/2008/index.php. Acesso em: 9 nov. 2009.

SINDUSCON-SP - Sindicato da Construção de São Paulo. Encargos Sociais, Out. 2009. Disponível em http://www.sindusconsp.com.br/downloads/estprod/economia/2009/enc1009.pdf. Acesso em: 9 nov. 2009.

\section{NOTES}

\footnotetext{
${ }^{\mathrm{i}}$ According to the Bovespa Newletter (2008), 64 companies went public in 2007. The civil construction sector ranked first place in the amount of companies (14) and second in value offered in the IPOs, corresponding to $15 \%$ of the total.

ii The PAC was launched in 2007, expected to invest $\mathrm{R} \$ 503$ billion over the next four years, in the sectors of infrastructure and housing, with funds from the Federal Government Budget. For housing, R\$106.3 billion will be destined, where $\mathrm{R} \$ 55.9$ billion are to be invested in financing programs for home ownership for families with incomes below five minimum wages. In infrastructure, the construction of 42,000 kilometers of roads and 2,518 $\mathrm{km}$ of railways is planned, and the expansion of 12 ports and 20 airports (DNIT, 2009).

iii See, for example, Arcoverde Tannuri-Pianto and Sousa (2009); Rocha and Sousa (2007); Sampaio, Ramos and Sampaio (2005); Figueiredo (2007a); Figueiredo (2007b); Barreto, Marinho and Oliveira (2002); Sampaio and Sampaio (2007) and Mello (2003).

iv See, for example, Jan (1996), Edvardsen (2003), NSCIC (2003), Chau and Wang (2003) and Ngyuen and Giang (2005).

${ }^{v}$ The position on the frontier is necessary, but not sufficient for efficiency. The absence of wastage in the firm characterized by the sum of the float variables equal to zero - is also required.

${ }^{v i}$ The explanations of constant returns and variable returns to scale are detailed in the next section, when the methodology of data envelopment analysis (DEA) is introduced

vii The terms are derived from the initials of its authors: CCR for Charnes, Cooper and Rhodes (1978) and BCC for Banker, Charnes and Cooper (1984). Alternatively, the first can be defined as CRS (constant return to scale) and VRS (variable return to scale).

viii If $\left(\mathrm{u}^{*}, \mathrm{v}^{*}\right)$ is a solution to the problem, then $\kappa \mathrm{u}^{*}, \mathrm{v} *<$ is also another possible solution, and so on.
} 


\footnotetext{
${ }^{\text {ix }}$ It should be emphasized, however, that the orientation of product or input, when working with firms operating at constant returns to scale, returns to the same value. In contrast, the companies will present different scores when considered in environment of variable returns of scale.

${ }^{x}$ Participation in the yearbook is optional, and the data provided by the participating companies through extensive form available via e-mail or internet.

${ }^{x i}$ In terms of revenue, construction companies in the sample represent a significant percentage of the total. In contrast, the representativeness of the sample according to the total amount of firms that operate in the construction industry is small. Moreover, the sample is concentrated in high revenue companies, most of them being located in the Southeast.

xii http://www.uq.edu.au/economics/cepa/deap.htm.

xiii The present study, for the reasons given above, relied on the multistage DEA methodology.

${ }^{x i v}$ The average is more sensitive to extreme points in relation to the median. The results indicate that some firms of greater technical efficiency boost the average up, with a slight distortion of the scores in respect to the median. Nevertheless, the conclusions are similar: increase in scores between 2005 and 2006 and decrease thereafter. However, technical efficiency, at the end of 2008 , is slightly higher than in 2005 , contrary to that observed in the calculation of average.

${ }^{\mathrm{xv}}$ The classification by revenue strata through the median returned to very similar results to those found for the average. The only difference is that, except for firms in the stratum of $\mathrm{R} \$ 100-500$ million revenue, there was an increase in the technical efficiency score compared to 2008.

${ }^{x v i}$ The results for the analysis via median were very close to those found through the average.

${ }^{x v i i}$ According to the report issued by Sinduscon-SP in October 2009.

xviii According to the São Paulo Housing Union- SECOVI-SP, at the end of 2007, 196,000 properties were

funded by the Housing Finance System (HFS), with a total of R 18 billion invested in the Brazilian System of Savings and Loan (SBPE). Compared to 2006, there was an $86.3 \%$ growth in unit volume and $92.6 \%$ in value.

xix The index of the Unit Cost of Construction (CUB) accumulated a 7.10\% rise between March and December 2007 , according to a report of the SINDUSCON-SP.
} 